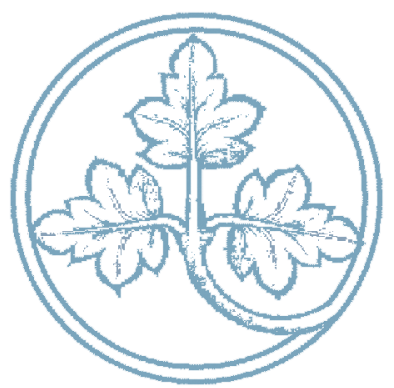

The design of licensing contracts: Chemicals, Pharmaceuticals, and Electrical Engineering in Imperial Germany

Carsten Burhop

Thorsten Lübbers

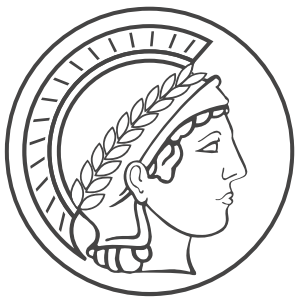




\section{The design of licensing contracts: Chemicals, Pharmaceuticals, and Electrical Engineering in Imperial Germany}

Carsten Burhop / Thorsten Lübbers

July 2011 


\title{
The design of licensing contracts: Chemicals, Pharmaceuticals, and Electrical Engineering in Imperial Germany*
}

by

\author{
Carsten Burhop ${ }^{\ddagger}$ and Thorsten Lübbers ${ }^{\dagger}$
}

\begin{abstract}
We investigate a sample of 180 technology licensing contracts closed by German chemical, pharmaceutical, and electrical engineering companies between 1880 and 1913. Our empirical results suggest that strategic behaviour seems to be relevant for the design of licensing contracts, whereas inventor moral hazard and risk aversion of licensor or licensee seem to be irrelevant. Moreover, our results suggest that uncertainty regarding the profitability of licensed technology influenced the design of licensing contracts. More specifically, profit sharing agreements or producer milestones were typically included into licensing contracts.
\end{abstract}

JEL-Classification: N83, O32, L14

Keywords: Economic History; Germany; pre-1913; Licensing contracts; Technology transfer

We would like to thank Christoph Engel, seminar participants in Bonn, Bochum, Hanover, Yale and two anonymous referees for many helpful comments. Moreover, we would like to thank the staff of the corporate archives of BASF, Bayer, Merck, and Siemens, the staff of Histocom (Hoechst archive) and of Deutsches Technikmuseum Berlin (AEG archive). Brian Cooper substantially improved the writing of the paper. Financial support of the Deutsche Forschungsgemeinschaft is gratefully acknowledged.

$\ddagger \quad$ Max-Planck-Institut zur Erforschung von Gemeinschaftsgütern \& Universität Köln

$\dagger \quad$ Max-Planck-Institut zur Erforschung von Gemeinschaftsgütern 


\section{Introduction}

Today, licenses are a common instrument of the owners of patents to make their innovation accessible to other users. This is, in general, good for users as well as innovators, since it generates profits and license fees for licensor and licensee. Consequently, many innovators share their patents via licensing contracts: In a survey of U.S. patent holders, nearly 18 percent of all patents in the respondents' patent portfolio were licensed (Scotchmer, 2006: 161). Moreover, about 20 percent of the foreign direct investment income of U.S. multinational companies is currently generated from technology licensing agreements (Vishwasrao, 2007).

Prospering markets for technology are not a recent phenomenon. They already existed in the U.S. during the mid- $19^{\text {th }}$ century facilitating the transfer of patents from individual inventors to firms. In particular, Lamoreaux and Sokoloff $(1999,2001)$ demonstrate that a large fraction of U.S. patents were fully or partially assigned by the inventor. During the 1870 s, inventors commercialised their ideas themselves, but often granted geographically bounded licenses to producers in distant regions. At the turn of the century, innovation and commercialisation were increasingly separated activities and inventors sold or licensed their patents to firms. The use of licenses to commercialise innovations is also highlighted by Khan and Sokoloff (1993) and by Lamoreaux and Sokoloff (2000), who describe some of the licensing contracts closed by America's great inventors during the $19^{\text {th }}$-century and the means of technology transfer in the American glass industry in the late $19^{\text {th }}$ - and early $20^{\text {th }}$-century, respectively. The processes culminated with the outsourcing of research tasks and close collaboration between in-house researchers and specialised free-standing research laboratories (Mowery, 1983).

Patent assignments and licensing contracts were also used in Germany since the late $19^{\text {th }}$ century. Burhop (2010) shows that 8.3 percent of all patents issued in Germany between the 1880s and World War I were transferred. Beyond such aggregate data, case studies of innovation procurement of German chemical and pharmaceutical companies at the turn of the $20^{\text {th }}$ century suggest a significant flow from outside inventions into new products. For example, Wimmer (1994) and Burhop (2009) illustrate that professionally managed in-house pharmaceutical product development was constricted to Bayer, whereas Hoechst and Merck procured new products from universities and free-lance inventors and only improved the production process in-house. Furthermore, Burhop (2009) shows that Hoechst, Merck, BASF, and Bayer acquired a large number of patents on the technology market. Between 1891 and 1913, these firms developed close to 5,000 patents in-house and acquired about 150 patents on the market. This seems to be a small number, but most of the external inventions were very valuable. For example, the ten most successful drugs sold by Merck between 1891 and 1918 were all invented by outside inventors. For Hoechst, Wimmer (1994: 183) demonstrates a similar relevance of outside inventors: 21 out of 24 bestselling drugs were procured from outsiders. In addition, Wimmer (1994) and Burhop (2009) show that most patents granted to Hoechst and Merck were patents improving an outside acquired technology. 
So far, no comprehensive historical study on the licensing activity and the design of licensing contracts of German companies is available. Only some evidence from studies that focus on either the research activities or the general history of specific companies exists. In his study on the synthetic dye research programmes of BASF and Hoechst, Reinhardt (1997) gives a detailed account of the companies' cooperation with individual researchers. In addition, he briefly mentions licensing agreements that BASF and Hoechst closed with other companies. For the pharmaceutical research activities of Bayer, Hoechst, and Merck, Wimmer (1994) provides details about these companies' cooperation with individual researchers, too. Furthermore, he also investigates in depth several licensing contracts with companies. Some information on both, licensing contracts with companies and the cooperation with individual researchers is available in Abelshauser's (2002) monograph on the corporate history of BASF, Burhop's (2009) article on Merck, Reinhardt's (1995) work on pharmaceutical research at BASF, and Reinhardt and Travis' (2000) study on Heinrich Caro, BASF's head of research. Finally, Pohl (1988) and Strunk (2000) as well as Feldenkirchen (2003) and Weiher and Goetzler (1981) here and there refer to licensing contracts closed by the electrical engineering firms AEG and Siemens, but hardly ever offer detailed information on the agreements. Thus, a number of case studies are available. However, they lack a common structure, making comparison and analysis in light of theory difficult. ${ }^{1}$

Economic theory has produced scores of models explaining licensing activity and the optimal structure of contracts. The typical model starts with the assumption that a licensing market exists $^{2}$ and that contracts are structured around a fixed fee and a per-unit royalty to address strategic concerns of the licensor regarding the product market behaviour of the licensee (see, e.g., the seminal model by Gallini and Wright, 1992). More recently, theorists focus on issues like uncertainty, risk aversion, and moral hazard. Section III of this paper give a short review of key licensing models.

Our empirical results, presented in Sections IV and V, based on 180 licensing contracts closed in Germany's chemical, pharmaceutical, and electrical engineering industries between 1880 and 1913, suggest that strategic behaviour seems to be relevant for the design of licensing contracts, whereas inventor moral hazard and risk aversion of licensor or licensee seem to be hardly relevant. Moreover, our results suggest that uncertainty regarding the profitability of licensed technology influenced the design of licensing contracts. More specifically, profit sharing agreements or producer milestones were typically included into licensing contracts. Beyond our contribution to economic history, we thus contribute to the empirical industrial organization literature. Most empirical studies investigating licensing contracts do not contain much information about the details of the contracts. The main reason for this gap is that the licensing agreements are private contracts, which are unobservable to the researcher most of the time. For example, less than ten percent of licensors sent the questionnaire back in one of the most comprehensive studies of licensing contracts (Brousseau et al., 2007). Consequently, econometric investigations of licensing

1 In a recent contribution, Lübbers (2009) analyzed cross-licensing agreements and thereby complements our paper, which base exclusively on one-way licensing agreements.

2 See, e.g., Arora et al., 2007, for a general discussion of the problems related to the existence of technology markets 
behaviour often employ binary choice variables indicating if a licensing contract was closed (or not) as dependent variable and a set of observable firm- or industry-specific variables as explanatory variables (Anand and Khanna, 2000). Starting with the work by Mendi (2005) and Vishwasrao (2007), researchers evaluated official forms filled by the licensees of cross-country licensing agreements to evaluate the content of licensing contracts. The official forms, however, do not contain the original licensing contract, but only some binary coded information of interest to the government. More recently, Sakakibara (2010) evaluated a sample of licensing contracts closed by Japanese firms during the late 1990s and early 2000s.

\section{Historical background}

During the second half of the $19^{\text {th }}$ century, Germany was transformed from a rural economy to one of the leading industrialised countries in the world. Between 1851 and 1913, the real net national product (NNP) increased by almost 2.5 per cent per annum (Burhop and Wolff, 2005). At the same time, the share of the agrarian sector in the German workforce decreased at the expense of the industrial sector (Pierenkemper and Tilly, 2004, 18-21). The leading sectors in the early years of Germany's industrialisation were transportation (i.e., railways) and also, to a smaller extent, iron and steel production as well as mining. Then, from the 1870 s onwards, in an accelerating process that is often referred to as the 'Second Industrial Revolution', two other sectors gained ever greater importance: the chemical industry and electrical engineering.

The growth of the chemical industry was, first of all, fuelled by advances in the fabrication of synthetic dyes from coal tar. Later on, pharmaceutical innovations and breakthroughs in inorganic chemistry became almost equally important. ${ }^{3}$ Between 1891 and 1913 , the output of the chemical sector increased by an annual rate of 6.4 per cent (Hoffmann, 1965, 361-362). The growth rate of electrical engineering was even more impressive: Total sales in the sector grew on average by more than 16 percent annually during the same period (Schulz-Hanßen, 1970, 29-31). The major factor behind this impressive growth was the introduction of electrical energy and its utilisation in a wide area of applications, such as transportation, lightning, and power generation. ${ }^{4}$

The Second Industrial Revolution can also be understood by looking at patenting activity. By investigating long-living patents (i.e., patents in force for at least ten years), Streb et al. (2006) identify four major technology booms between 1877 and 1918. The first boom occurred between 1877 and 1886. It is labelled "railway wave", since most valuable patents were used in this industry. The second and the third boom (1887 to 1896 and 1897 to 1902) were shaped by the chemical industry and are labelled the "dye wave" and the "chemical wave", respectively. The final boom, which lasted from 1903 up to the end of the First World War, is identified as the "wave of electrical engineering".

3 On the development of the chemical industry in Germany, Europe, and the USA, see Beer (1959); Haber (1958); Homburg, Travis, and Schröter (1998).

4 On the development of electrical engineering, see the literature on the two major companies, AEG (Pohl, 1988; Strunk, 2000) and Siemens (Feldenkirchen, 2003; Kocka, 1969). 
Apart from the impressive quantitative changes, an important qualitative innovation took place during the late $19^{\text {th }}$ and early $20^{\text {th }}$ century: the incorporation of science into industrial production and the industrialisation of scientific research. Beginning in the $1870 \mathrm{~s}$, the companies from the chemical industry made increasing use of the abundant reservoir of scientifically trained chemists: at first, by deepening their cooperation with universities and other external research facilities; ${ }^{5}$ then, in a next step, by the internalisation of scientific research. The major companies from the chemical industry - BASF, Bayer, and Hoechst - hired an ever-growing number of university-trained scientists between the late 1870s and early 1890s and founded central research laboratories (Homburg, 1992). Electrical engineering profited from the translation of engineering from a practically orientated occupation to a scientific discipline that was taught at universities and other institutions of higher education (König, 1996). In addition, and as a result of this development, the companies from this sector also increased their research staff. However, the internalisation of scientific research was not conducted on the same scale and with the same rigour as in the chemical industry. ${ }^{6}$

Apart from substantial investment in universities and other research facilities, an important political contribution to the emergence of the knowledge-based economy was the enactment of the first federal German patent law in 1877. In the preceding years, a patchwork of numerous patent legislations existed in the individual German states, and in many cases, the state authorities regarded patents as privileges rather than as rights. ${ }^{7}$ The first federal patent law of 1877 included some stipulations that supported the interest of industrial companies vis-à-vis individual inventors. At first, a patent did not necessarily belong to the inventor, but was granted to the person or institution who registered it at the patent office. ${ }^{8}$ This stipulation allowed companies to apply for patents of inventions made by their employees in the companies' names. Thus, it facilitated their research activities based on division of labour. ${ }^{9}$ Second, a patented invention had to be worked. If the patentee did not do so herself or licensed the patent, the protection could disappear after three years. In effect, this stipulation favoured companies over individual inventors, as individuals were usually unable to produce an invention themselves. Furthermore, the duty to use a patent hindered strategic patenting behaviour aimed at the blockade of market entrants, because companies could not apply for a wide range of patents in one line of business without being able or willing to use all the property rights. Third, all patent applications were made subject to a thorough pre-examination by the German patent office, which had to judge whether the application really constituted a patentable invention (Seckelmann, 2006, 257-260). This stipulation

5 There are numerous studies on the linkage between the state, universities, and the chemical industry. See, e.g., Borscheid (1976), Murmann (2006), and Wetzel (1991).

6 Siemens had not created a central research laboratory until the beginning of the 1920s. However, this does not mean that that no research took place within the company, but that it was decentralised in diffferent departments and various small laboratories. On the development of research at Siemens, see Erker (1990), Hack (1998: 109-118), Trendelenburg (1975: 1-50), and Schubert (1987). A comprehensive study on the organisation of research at AEG is not available.

$7 \quad$ For the history of the patent laws of different German territories, see Heggen (1975), Seckelmann (2006, 57106).

8 The patent law of 1877 and the revised version of 1891 are printed in Seckelmann (2006, 427-436, 440-451).

9 The emerging moral hazard problem inside the firm was solved by closing incentive contracts with the employed scientists (Burhop and Lübbers, 2010). 
again hindered the blockade of actual or potential competitors, as it also reduced the possibility of extensive patenting. Finally, the patent fees that had to be paid annually in order to uphold a patent for another year were designed progressively. ${ }^{10}$ These again favoured companies over individual inventors, as the latter might in many cases not have been able to pay the renewal fees. Moreover the high renewal fees also hindered excessive patenting activity and a blockade of technological progress, as a patent owner would uphold meaningful and valuable patents only.

For the emergence of the market for technology licenses, some of the above-mentioned peculiarities of the German patent law proved beneficial: The compulsory working of a patent and the progressive nature of the renewal fee must have substantially increased the willingness of individual inventors - and also of firms - to share their findings with industrial partners, as they would have been unable to exploit them themselves. Moreover, the in-depth pre-examination by the patent office increased potential licensees' willingness to pay, as it made it less likely that a patent would be successfully attacked by litigation once it was granted. ${ }^{11}$

\section{Theory}

The theoretical literature about the optimal design of technology licensing contracts is quite advanced and far ahead of empirical contributions. Early papers investigate strategic considerations of an innovative firm to license a new technology to a competing firm. More recently, extensions and variations of classical licensing models consider risk-aversion, moral hazard, and uncertainty. In general, the models yield partly conflicting results regarding the optimal contract structure. Thus, depending on the model, the optimal contract can contain a fixed upfront payment, fixed annual payments, or payments if certain milestones are reached, per-unit royalties, turnover or profit shares.

It is important to note that per-unit royalties and turnover sharing agreements typically imply deadweight losses, whereas milestones, fixed payments, and profit shares do not affect aggregate welfare. For example, if a technology is licensed to only one producer, this monopolist maximises his profit if marginal revenues equal marginal costs. A per-unit royalty obviously affects the cost function - marginal costs are higher, the optimal output therefore lower. In a similar way, a turnover sharing agreement affects the revenue function. Thus, this type of contract also induces a deadweight loss. In contrast, profit sharing agreements neither affect the revenue nor the cost function. Moreover, any kind of fixed transfer (upfront, annually, milestone) does not influence the first order conditions. Thus, profit sharing agreements and any kind of fixed payments do not induce deadweight losses. Yet, profit sharing agreements are often difficult to enforce since the profits stemming from one specific licensing agreement have to be calculated. Thus, relatively

10 The fee was 50 Mark for the first and 50 Mark for the second year. Afterwards, the fee increased by 50 Mark each year. If a patentee wanted to uphold a patent for the maximum period of 15 years, he thus had to pay 700 Mark in the last year and 5,300 Mark in total. This compares to an annual per capita income of about 800 Mark in 1913.

11 Secure property rights were also highlighted by Khan (1995) and Khan and Sokoloff (2004) as relevant for the emergence of the U.S. market for patent assignments and technology licenses. 
high monitoring and enforcement costs of profit sharing agreements make milestones an attractive contractual choice.

Early licensing models focus on strategic considerations of an innovative and simultaneously producing firm licensing a technology to a competing firm. In such a case, per-unit royalties or turnover shares can be used to influence the marginal costs of the licensee and thereby the licensor controls the optimal output of the licensee. Thus, strategic considerations of the licensor result into a contract which maximizes the income of the licensor, but which is inefficient from an aggregate welfare perspective. In addition, a fixed fee helps that the participation constraints of licensor and licensee are satisfied, i.e. that a licensing contract is signed at all. Moreover, if future profits are known ex ante, the present value of royalties can be calculated and transformed into a fixed upfront payment. Thus, contracts containing only a fixed upfront payment can be optimal under certain circumstances (Katz and Shapiro, 1985; Shapiro, 1985; Kamien and Tauman, 1986; Wang, 1998).

An important extension of this classical set-up is the model proposed by Bousquet et al. (1998). They consider a world with uncertainty for all parties regarding the amount of cost savings realized using an innovation or the profits generated producing a new product. Moreover, they assume a risk-averse licensee, whereas the licensor is risk-neutral. ${ }^{12}$ Under cost uncertainty and with a risk-averse licensee, per-unit royalties can increase aggregate utility, since the insurance effect of a royalty can overcompensate for the output distortion induced by the per-unit royalty. A risk-averse firm gets higher utility from a low, but save payment compared to a potentially high, but risky payment. A similar result holds in case of demand uncertainty. Again, a riskaverse licensee has a preference for insurance. In case of demand uncertainty, Bousquet et al. (1998) show that the best licensing contract is a turnover sharing agreement combined with a per-unit royalty or a turnover sharing agreement combined with a non-negative fixed fee. In sum, the type of innovation can substantially affect optimal contract design in case of uncertainty and risk-averse licensees.

The effect of moral hazard on the design of optimal licensing contracts has been investigated by Jensen and Thursby (2001). They start from the assumption that an external, risk-neutral innovator licenses a new technology to a risk-neutral producer. The new technology is not fully developed at the time the licensing agreement is signed and some effort of the inventor is necessary to get the new product to the market or to put the new process into use. ${ }^{13}$ The inventor dislikes effort but likes money and the licensee must thus choose a contract that motivates the licensor to put effort into the new technology after the contract has been signed. The effort of the licensor is increasing in the per-unit royalty (or turnover share) as long as the income from this source increases. However, the per-unit royalty (or turnover share) affects the optimization conditions of the licensee and it is possible that the profit maximizing output choice of the licensee is too low to yield the royalty income necessary to induce optimal licensor effort. In contrast, the optimal

12 Jensen and Thursby (2001) model risk-aversion of the licensor in a moral hazard framework.

13 Agrawal (2006) shows that an increased level of engagement of the licensor by the licensee after signing of a licensing contract increases the odds of commercialisation of a product substantially. 
effort as well as the optimal output is always realized whenever licensor and licensee sign a profit sharing contract, since a profit share does neither affect the cost nor the revenue function of the producer. Consequently, if a high effort of the inventor is necessary to get the innovation into use, it is possible that such a high effort is only possible with a royalty rate higher than the licensing-revenue-maximizing royalty rate. Thus, the moral hazard problem cannot be fully solved in this case. This cannot occur in profit-sharing agreements since the effort is strictly increasing in the profit share. ${ }^{14}$

A major problem of profit sharing agreements are high monitoring and information costs associated with such agreements. In general, the licensee has to calculate the profits resulting from a specific licensing agreement and the licensor has to audit this calculation. To circumvent deadweight losses resulting from per-unit royalties or turnover sharing agreements as well as monitoring problems resulting from profit sharing agreements, Dechenaux et al. (2009) propose milestone payments of the licensee to the licensor to solve the moral hazard problem. Whenever a certain, well-defined milestone (e.g. patent grant, first product sold etc.) is reached, the licensor receives a payment from the licensee. Thus milestones solve the same problem as profit-sharing contracts, i.e., milestones can complement or substitute profit-shares in contract choice. Closely related is the model proposed by Dechenaux et al. (2011). They consider a risk-averse licensee using milestones to overcome moral hazard. If the licensee is risk-averse she does not like milestone payments based on technical success. In the worst case, the invention is a technical success, but a commercial failure. In this case, the inventor receives milestone payments and the producer makes a loss. If the inventor is risk-neutral, part of the milestone payment can be replaced by a turnover share or a per-unit royalty. Thus, milestone payments and per-unit royalties (or turnover shares) can be simultaneously contained in a licensing agreement. ${ }^{15}$

\section{Data sources and descriptive statistics}

The information on the licensing agreements evaluated in this paper is gathered from archival sources. We selected seven companies for our study. ${ }^{16}$ Three of them - Allgemeine ElektrizitätsGesellschaft (AEG), Telefunken, and Siemens - were engaged in electrical engineering, the other four - Bayer, BASF, Hoechst, and Merck - are from the chemical and pharmaceutical industry. Our sample thus covers the major companies from the two leading sectors of the Second In-

14 Aghion and Tirole (1994a, 1994b) are concerned with the optimal distribution of profit shares if effort of both parties, licensor and licensee, is necessary to develop the invention towards the market. For example, inventor effort is useful to improve the new technology, whereas the producer has to invest into production facilities or marketing of the new product. The main proposition of Aghion and Tirole is that the higher the necessary effort of one party, the higher its profit shares.

15 Moreover, Dechenaux et al. (2011) demonstrate that the incentive pay of the inventor can be replaced by a fixed consulting fee if the producer can (perfectly) monitor the consulting effort of the inventor. For example, the inventor can work in the laboratories of the producers to improve the licensed technology to the market. This seems to be a small sample, but since we hand-collected the data from corporate archives, we decided to focus on firms active in technology-intensive branches. Moreover, the records of the firms must be available for inspection. 
dustrial Revolution. BASF, Bayer, and Hoechst were the dominant players on the market for synthetic dyes and - with the exception of BASF - also in the fabrication of pharmaceutical innovations. Merck was of smaller size and engaged in pharmaceuticals and specialised chemicals. AEG, Siemens, and their joint-venture Telefunken dominated electrical engineering. ${ }^{17}$

In total, we were able to gather 180 licensing contracts closed between 1880 and 1914.159 of the contracts are from the chemical and pharmaceutical industry and 21 are from electrical engineering companies. Most of the available contracts from the chemical and pharmaceutical companies were closed during the 1890 s, a slightly smaller number in the years between the turn of the century and the First World War. For the electrical engineering companies, 20 out of 21 agreements are from the $20^{\text {th }}$ century. In 169 cases, the seven firms were the licensees, in the remaining eleven the licensors. 74 contracts are from Hoechst, 42 from Bayer, 28 from Merck, nine from Telefunken, six from Siemens, six from BASF, and four from AEG. ${ }^{18}$

From all of the 180 licensing contacts, we were able to gather information on the following features: 1) contracting parties, 2) scope of the agreement, 3) licensing fees, 3) duration of the contract, 4) pre- or post-patent contracting and 5) auditing rights. Only in two cases, an individual appeared as licensee. The findings on the licensors are less clear-cut. Overall, in one-fourth of the available contracts, the licensor was a company, in the remaining cases one or more individuals licensed the product or process. ${ }^{19}$ Furthermore, in one out of six contracts, strategic behaviour might have influenced contract design since both, licensor and licensee, were firms active in the same industry.

17 We were unable to collect firm-specific data since two of the firms (Merck, Telefunken) were non-listed companies without any obligation to publish information. Moreover, even the published information of listed companies (e.g. turnover, profit, number of employees) is in general unavailable in a comparable format. It is quite difficult to locate licensing agreements in the files of the seven firms. For one firm, AEG, we discovered aggregate information about licensing of this firm between 1891 and 1913. The total number of licensing contracts closes by AEG during that period was about 1,000; only four of them could be located in the archive. 
TABLE 1:

FRACTION OF LICENSING CONTRACTS CONTAINING THE FOLLOWING CLAUSE

\begin{tabular}{|c|c|c|c|c|c|}
\hline & Feature / Sector & $\begin{array}{c}\text { Chemical \& Phar- } \\
\text { maceutical }\end{array}$ & $\begin{array}{l}\text { Electrical En- } \\
\text { gineering }\end{array}$ & $\begin{array}{l}\mathrm{p} \text {-value of } \\
\text { Fisher's } \\
\text { exact test }\end{array}$ & TOTAL \\
\hline \multicolumn{2}{|c|}{ Number of observations } & 159 & 21 & & 180 \\
\hline \multirow{2}{*}{\multicolumn{2}{|c|}{$\begin{array}{l}\text { Firm as licensor } \\
\text { Strategic licensing possible }\end{array}$}} & $20.1 \%$ & $57.1 \%$ & 0.000 & $24.4 \%$ \\
\hline & & $13.2 \%$ & $38.1 \%$ & 0.004 & $16.1 \%$ \\
\hline \multirow[t]{7}{*}{ Payment } & Up-front fix & $25.2 \%$ & $47.6 \%$ & 0.039 & $27.8 \%$ \\
\hline & Annual fix & $9.4 \%$ & $9.5 \%$ & 0.989 & $9.4 \%$ \\
\hline & Inventor milestone & $7.5 \%$ & $0.0 \%$ & 0.194 & $6.7 \%$ \\
\hline & Producer milestone & $26.4 \%$ & $4.8 \%$ & 0.029 & $23.9 \%$ \\
\hline & Profit share & $71.7 \%$ & $0.0 \%$ & 0.000 & $63.3 \%$ \\
\hline & Revenue share & $8.2 \%$ & $66.7 \%$ & 0.000 & $15.0 \%$ \\
\hline & Quantity share & $17.0 \%$ & $33.3 \%$ & 0.081 & $18.9 \%$ \\
\hline \multirow[t]{2}{*}{ Duration } & Patent duration & $86.8 \%$ & $61.9 \%$ & 0.008 & $83.9 \%$ \\
\hline & Years & 14.8 years & 8.4 years & & 13.0 years \\
\hline \multicolumn{2}{|c|}{ Exclusive license } & $89.3 \%$ & $61.9 \%$ & 0.003 & $86.1 \%$ \\
\hline \multicolumn{2}{|c|}{ Auditing right } & $21.4 \%$ & $42.9 \%$ & 0.001 & $23.9 \%$ \\
\hline \multicolumn{2}{|c|}{ Pre-patent contracting } & $57.9 \%$ & $23.8 \%$ & 0.004 & $53.9 \%$ \\
\hline
\end{tabular}

Source: Archival database. Fisher's exact test tests the null hypothesis of equal means in the two samples.

Our data indicate that individual inventors transferred technology to firms, which have better complementary assets to use the technology. Some individual inventors interacted several times with the same firm. For example, Alfred Baeyer licensed in 1880 a process for synthetic indigo and in 1887 a process for fuchsine to Bayer. His student Emil Fischer also got into a long-term relationship with Bayer. Between 1905 and 1913, Fischer licensed five inventions to this firm. Moreover, the case of Fischer indicates that competition between firms existed. In 1903 and 1905, Fischer licensed innovations to Hoechst and Merck. Competition between firms and long term relations with a certain firm can also be observed in the case of Joseph von Mering. Between 1897 and 1903, von Mering licensed three products to Merck. Later on, in 1905, he licensed another product to Hoechst. Other examples for multiple interactions between certain inventors and firms are documented in the data. Oscar Hinsberg licensed two products to Hoechst - the first in 1902, the second in 1910. Furthermore, Karl Fries licensed three innovations to Hoechst between 1904 and 1912.

Turning to licensing fees, we find that upfront fixed payments were more common in electrical engineering, but less often contracted in chemicals and pharmaceuticals. In the former, almost half of the licensing agreements included an upfront fixed payment; in the latter, in roughly one

19 The great importance of individual inventors for the development of new technology has been highlighted by Nicholas $(2009,2010,2011)$ for the United States, the United Kingdom and Japan as well as by Burhop (2010) for Germany. 
quarter of the cases, upfront fixed payments were agreed on. About one-tenth of the contracts in both industries specified annual payments. In addition, some contracts from the chemical industry specified milestone payments conditioned on some activity related to the inventor, e.g., the grant of a patent or successful clinical trials. In addition, about one quarter of the contracts from the chemical industry but only five percent of the contracts from the electrical engineering industry specified a producer milestone. A producer milestone specified a payment to the licensor whenever some output or sales milestone was reached.

In four contracts from the chemical and pharmaceutical industry, an upfront fixed payment was the only payment made. One company, Siemens, hardly ever agreed on upfront fixed payments. Only in one of Siemens' contracts, in which the company appeared as joint licensee with AEG, such a payment was included. The average upfront fixed fee amounts to 9,237 Mark. Yet, the variation of the upfront fixed fees is substantial, ranging from zero to 630,000 Mark. ${ }^{20}$

Nearly all contracts included some kind of variable payment. In general, these took four different forms: 1) a percentage of the profits generated by the licensed product or process, 2) a percentage of its revenue, 3 ) per piece or with reference to some other physical attribute (e.g., per kilo, per litre, per kilowatt) of the licensed product or process, and 4) other forms of variable payments (e.g., a percentage of the cost reductions due to the licensed technology). In electrical engineering, fees as a percentage of profits seem to have been uncommon, as they appeared in none of the available contracts. In contrast, most of the available agreements from this sector included variable payments that were calculated as a percentage of revenues. In almost all other cases, fees calculated on the basis of a physical attribute were agreed on. The picture in the chemical and pharmaceutical industry looks completely different. Here, variable payments that were calculated as a percentage of profits were the rule. In more than 70 per cent of the cases, the contracting parties agreed on this type of variable payment. Moreover, it should be noticed that the sharing rates were relatively high. The average licensor profit share was 20.7 percent, the average turnover share 10.4 percent. ${ }^{21}$

Wimmer (1994) and Burhop (2009) demonstrate that Hoechst and Merck kept detailed productspecific accounts to calculate the profit shares. Both firms calculated the product-specific profit as the turnover less the variable and the fixed costs. The fixed costs (i.e., capital costs) were calculated as a percentage depreciation of the capital goods (machinery, buildings) used for the production of each product. The firms kept separate investment accounts for each product. Overhead costs were allocated using the turnover of the products as a distribution key. One should note that the licensor received a share of the product specific profits, not a share of the patent specific profits. Thus, all refinements made by the licensee were automatically covered by the licensing agreement. Merck, for example, kept accounts containing information about revenues, production costs, and marketing expenditures for up to 78 products during the pre-1913 period. The firm tracked the production costs, including the ongoing expenses for chemicals, heating materi-

20 This compares to a per-capita income of 800 Mark in 1913.

21 This compares, for example, to an average turnover share of only 3.6 percent in a sample of modern Japanese licensing contracts (Sakakibara, 2010). 
als, and wages, as well as gathering information about depreciation (capital costs) for the capital stock used to produce each product. Overhead costs were also allocated to the products according to turnover generated by each product. The accounting method was standardized and, by and large, the accounts seem to be undisputed since only one conflict regarding the accounts is documented for the pre-1913 period.

The duration of the available licensing agreements was longer in the chemical and pharmaceutical industry and more often based on the patent duration. In almost 87 per cent of the cases the duration of the contract was linked to the duration of the respective patent. ${ }^{22}$ In the remaining cases, the average contract period was 14.8 years. In electrical engineering, the share of those contracts whose duration was linked to the duration of the respective patent was substantially smaller than in the chemical and pharmaceutical industry. However, more than 60 per cent of all contracts were of this type. The average contract period of the other agreements was 8.4 years.

Another difference between the chemical and pharmaceutical industry, on the one hand, and the electrical engineering industry, on the other, was the timing of the licensing agreement, i.e., whether at the time when the respective contract was closed, a patent on the respective product or process had already been granted or whether it was only applied for or intended to be applied for. In electrical engineering, in the overwhelming majority of the cases a patent existed at the time that the contract was closed. In contrast, in the chemical and pharmaceutical industry licensing contracts were more often agreed on at an early stage of the patenting process.

\section{Econometric evaluation}

Licensing models yield various and in part conflicting results. Moreover, some important variables are not directly observable, making an econometric test of the models difficult. Thus, some proxy variables are used in the econometric specifications. First strategic behaviour is reflected in a dummy variable taking the value one if licensor and licensee are both producers from the same industry. Second, fixed upfront fees in combination with some other payments to the licensor indicate risk-aversion of her, whereas fixed upfront payments without any other compensation scheme indicate the absence of any moral hazard problems or uncertainty regarding the future success of an invention. Third, we assume that non-patented inventions or inventions offered by individual inventors - who most likely do not possess the resources to develop an invention to the market - are early stage inventions. They are more likely to be licensed using a profit-sharing agreement or milestone payments. Moreover, looking only at profit-sharing and milestone agreements, the profit-share or milestone of the inventor should be higher for early stage inventions. In addition, we differentiate between inventor and producer milestones. If the inventor is responsible that a certain milestone (e.g. successful clinical trials, successful patent application) is reached, we call it 'inventor milestone'. If the producer is responsible that a certain milestone (e.g. number of units produced or sold) is reached, we call it 'producer milestone'. Inventor 
milestones should be significant for contract design if licensor moral hazard is important, whereas producers milestones could indicate producer moral hazard, risk-aversion of the producer or uncertainty regarding future profits.

The licensing models outlined in Section III suggest several hypotheses which can be tested with our data. According to the strategic licensing model, a licensor granting a license to a potentially competing producer from the same industry uses the licensing contract to determine the optimal output choice of the licensee. This can be achieved by a per-unit royalty or a turnover sharing contract - the first contract affects the cost function, the latter affects the revenue function. Moreover, a fixed upfront payment may be included into the contract to make sure that the participation constraints of licensor and licensee are met. We quantify this idea by estimating three probit models with different left hand side variables and identical explanatory variables. ${ }^{23}$ Our explanatory variables are the size of the fixed upfront payment and a dummy variable taking the value of one if both, licensor and licensee, are firms from the same industry. Using these explanatory variables, we assess if licensing contracts contain a per-unit royalty or a turnover sharing agreement. ${ }^{24}$

Table 2 shows the results. In regression (2a), the dependent variable takes the value one if the licensing contract contains a turnover sharing agreement, whereas in regression $(2 b)$, the dependent variable takes the value of one if the licensing contract contains a per-unit royalty. In regression (2c), the dependent variable takes the value of one if the licensing contract contains a turnover sharing agreement or a per-unit royalty. In all three cases $(2 a),(2 b)$, and (2c), the probability of having such a clause in the contract is higher when both contracting parties are firms from the same industry. The coefficients and marginal effects are significant at a one percent level in all three specifications and the marginal effects are substantial. For example, when licensor and licensee are from the same industry, the probability of closing a turnover sharing agreement is 38 percent higher compared to cases when licensor and licensee are not from the same industry. Thus, the results presented in Table 2, regressions (2a)-(2c) suggest that strategic concerns affected the design of licensing contracts at the turn of the $20^{\text {th }}$ century.

23 One should note that most variables are endogenous since all contractual terms are negotiated at the same time. However, this type of analysis is the standard approach in the literature. Nonetheless, the reader should keep this caveat into mind. Including firm- or sector dummies into the regression was impossible. 
Table 2: Strategic contract design

\begin{tabular}{|c|c|c|c|c|}
\hline \multirow[t]{2}{*}{ Explanatory variable } & $\begin{array}{l}\text { Turnover sha- } \\
\text { ring } \\
(2 \mathrm{a})\end{array}$ & $\begin{array}{c}\text { Per-unit royalty } \\
(2 \mathrm{~b})\end{array}$ & $\begin{array}{l}\text { Turnover shar- } \\
\text { ing or per unit } \\
\text { royalty } \\
(2 \mathrm{c})\end{array}$ & $\begin{array}{l}\text { Profit sharing } \\
\quad(2 \mathrm{~d})\end{array}$ \\
\hline & \multicolumn{4}{|c|}{ Regression coefficient } \\
\hline Fixed fee (in 1,000 Mark) & 0.002 & -0.003 & 0.002 & $-0.016 * *$ \\
\hline $\begin{array}{l}\text { Licensor is firm from } \\
\text { same industry }\end{array}$ & $1.275^{* * *}$ & $0.857 * * *$ & $1.602^{* * *}$ & $-2.128^{* * *}$ \\
\hline \multirow[t]{2}{*}{ Constant } & $-1.376^{* * *}$ & $-1.198^{* * *}$ & $-0.700 * * *$ & $0.733 * * *$ \\
\hline & \multicolumn{4}{|c|}{ Marginal effect } \\
\hline Fixed fee (in 1,000 Mark) & 0.000 & -0.001 & 0.001 & $-0.006^{* *}$ \\
\hline $\begin{array}{l}\text { Licensor is firm from } \\
\text { same industry }\end{array}$ & $0.380^{* * *}$ & $0.246^{* * *}$ & $0.574^{* * *}$ & $-0.660 * * *$ \\
\hline Constant & $-0.464 * * *$ & $-0.406 * * *$ & $-0.273^{* * *}$ & $0.284 * * *$ \\
\hline McFadden $\mathrm{R}^{2}$ & 0.159 & 0.062 & 0.156 & 0.230 \\
\hline Prob $\mathrm{Chi}^{2}$ test & 0.000 & 0.009 & 0.000 & 0.000 \\
\hline Number of observations & 180 & 180 & 180 & 180 \\
\hline
\end{tabular}

Method: Probit. ${ }^{*}, * * * * *$ denotes significance on ten, five, and one percent level, respectively.

Furthermore, this hypothesis is supported by regression (2d). In this regression, the dependent variable takes the value one if the licensing contract includes a profit sharing agreement. As outlined in the theoretical section above, profit sharing agreements cannot be used to affect the optimal output choice of the licensee. Consequently, profit sharing contracts should be less likely if strategic aims of the licensor affect the design of the licensing contract. Indeed, the regression coefficient of the variable 'Licensor is firm from the same industry' is significantly negative.

We now turn to uncertainty models with risk-averse licensees. Bousquet et al. (1998) show that licensing contracts should include a turnover share and a per-unit royalty or a turnover share and a fixed upfront payment in case of demand uncertainty. In case of cost uncertainty, the optimal contract usually contains all three instruments - turnover shares, per-unit royalties, and fixed upfront payments. The probit regression results displayed in Table 3 assess these predictions. ${ }^{25}$

25 Including firm- or sector dummies into the regression was impossible. 
Table 3: Uncertainty and contract design

\begin{tabular}{|c|c|c|c|c|}
\hline Explanatory variable & $\begin{array}{l}\text { Turnover sha- } \\
\text { ring } \\
(3 a)\end{array}$ & $\begin{array}{c}\text { Per-unit royalty } \\
(3 \mathrm{~b})\end{array}$ & $\begin{array}{l}\text { Turnover shar- } \\
\text { ing or per unit } \\
\text { royalty } \\
\text { (3c) }\end{array}$ & $\begin{array}{l}\text { Turnover shar- } \\
\text { ing or per unit } \\
\text { royalty } \\
\text { (3d) }\end{array}$ \\
\hline & \multicolumn{4}{|c|}{ Regression coefficient } \\
\hline Fixed fee (in 1,000 Mark) & 0.003 & -0.003 & 0.003 & 0.002 \\
\hline $\begin{array}{l}\text { Contract duration in } \\
\text { years }\end{array}$ & -0.000 & -0.000 & -0.000 & -0.000 \\
\hline Pre-patent contracting & $-0.832^{* * *}$ & $-0.899 * * *$ & $-1.208^{* * *}$ & $-1.158^{* * *}$ \\
\hline Producer milestone & & & & $-0.526 * *$ \\
\hline \multirow[t]{2}{*}{ Constant } & $1.622^{* * *}$ & $-1.564 * * *$ & $-1.112^{* * *}$ & $-0.963 * * *$ \\
\hline & \multicolumn{4}{|c|}{ Marginal effect } \\
\hline Fixed fee (in 1,000 Mark) & 0.001 & -0.001 & 0.001 & 0.001 \\
\hline $\begin{array}{l}\text { Contract duration in } \\
\text { years }\end{array}$ & -0.000 & -0.000 & -0.000 & -0.000 \\
\hline Pre-patent contracting & $-0.180 * * *$ & $-0.195^{* * *}$ & $-0.416 * * *$ & $-0.398 * * *$ \\
\hline Producer milestone & & & & $-0.170^{* *}$ \\
\hline Constant & $-0.558^{* * *}$ & $-0.536 * * *$ & $-0.421 * * *$ & $-0.370 * * *$ \\
\hline McFadden $\mathrm{R}^{2}$ & 0.108 & 0.098 & 0.166 & 0.184 \\
\hline Prob $\mathrm{Chi}^{2}$ test & 0.009 & 0.025 & 0.000 & 0.000 \\
\hline Number of observations & 180 & 180 & 180 & 180 \\
\hline
\end{tabular}

Method: Probit. *,***** denotes significance on ten, five, and one percent level, respectively.

In regression (3a), the dependent variable takes the value one if the contract contains a turnover sharing rule. In case of demand uncertainty, the fixed fee should be significant. This is not the case. In regression ( $3 b$ ), the dependent variable takes the value one if the contract specifies a perunit royalty. In case of cost uncertainty, the fixed fee could be significant. This is not the case. In regressions (3c) and (3d), the dependent variable takes the value one if the contract contains either a turnover sharing clause or a per-unit royalty. This contract choice is possible in the case of demand and cost uncertainty. Moreover, it is not necessary that such a contract contains a fixed fee. Thus, our finding of an insignificant impact of fixed upfront payments on variable compensation components is compatible with the model.

In addition, we try to capture uncertainty directly by including several control variables into the regressions. Our first uncertainty proxy is contract duration, measured in years. This variable is insignificant in all specifications. The second uncertainty proxy is a dummy variable taking the value one if the licensing contract is agreed upon before a patent was granted for the underlying technology. The technical screening of the patent application by the patent office guarantees 
technical feasibility of the underlying technology. Moreover, the patent guarantees the intellectual property right. Thus, the absence of a patent indicates a higher degree of technical and legal uncertainty and this should be addressed by the licensing contract. Therefore, we expect a positive and significant coefficient. However, in contrast to this hypothesis, the coefficient is significantly negative. The absence of a patent reduces the probability of agreeing on either a turnover sharing rule or a per-unit royalty by about 20 percent.

Furthermore, we assess an idea put forward by Dechenaux et al. (2011). They suggest that a riskaverse licensee may use milestone payments to compensate the licensor. In particular, milestones based on the commercial success can substitute turnover shares or per-unit royalties. Indeed, regression (3d) supports this idea. Contracts containing producer milestones are significantly less likely to contain turnover sharing clauses or per-unit royalties.

We now turn to models focusing on inventor moral hazard. The model developed by Jensen and Thursby (2001) suggests that a profit-sharing licensing contract is superior to a royalty contract if a large amount of inventor effort is necessary to commercialise an innovation. Thus, earlystage innovations, e.g., non-patented innovations and innovations made by individual inventors should be more likely to be licensed using profit-sharing contracts since they potentially require substantial effort of the inventor after licensing the technology. Moreover, theory suggests that the level of fixed upfront payments can influence the contract design if the innovator is riskaverse. We put three hypotheses to an econometric test: (i) non-patented innovations and innovations offered by individual inventors are more likely to be licensed using profit-sharing agreements; (ii) high fixed upfront payments increase the likelihood that a profit-sharing agreement is closed since risk-averse licensor are willing to sign the contract; (iii) high fixed upfront payments are correlated with higher profit shares. Hypothesis (i) should be rejected if inventor moral hazard was unimportant. Moreover, hypotheses (ii) and (iii) should be rejected, if the inventor is risk-neutral. The first two hypotheses are evaluated using a probit model (see Table 4), whereas the third hypothesis is assessed using OLS (see Table 5). 
Table 4: Moral hazard and contract design ${ }^{26}$

\begin{tabular}{|c|c|c|c|c|}
\hline \multirow[t]{2}{*}{ Explanatory variable } & $\begin{array}{c}\text { Profit sharing } \\
\text { contract } \\
(4 a) \\
\end{array}$ & $\begin{array}{l}\text { Profit sharing } \\
\text { contract } \\
(4 \mathrm{~b})\end{array}$ & $\begin{array}{l}\text { Profit sharing } \\
\text { contract } \\
(4 \mathrm{c}) \\
\end{array}$ & $\begin{array}{l}\text { Profit sharing } \\
\text { contract } \\
(4 \mathrm{~d})\end{array}$ \\
\hline & \multicolumn{4}{|c|}{ Regression coefficient } \\
\hline $\begin{array}{l}\text { Fixed fee (in 1,000 } \\
\text { Mark) }\end{array}$ & $-0.016^{*}$ & $-0.016^{*}$ & -0.013 & -0.014 \\
\hline Individual inventor & $1.794^{* * *}$ & $1.793^{* * *}$ & $1.611^{* * *}$ & $1.507 * * *$ \\
\hline Pre-patent licensing & $0.568 * *$ & $0.552 * *$ & $0.478^{*}$ & $0.482^{*}$ \\
\hline Inventor milestone & & 0.232 & 0.254 & 0.248 \\
\hline Auditing right & & & $-0.558^{*}$ & -0.498 \\
\hline Producer milestone & & & & $0.547^{*}$ \\
\hline \multirow[t]{2}{*}{ Constant } & $1.145^{* * *}$ & $1.123^{* * *}$ & $1.156^{* * *}$ & $1.013^{* * *}$ \\
\hline & \multicolumn{4}{|c|}{ Marginal effect } \\
\hline $\begin{array}{l}\text { Fixed fee (in 1,000 } \\
\text { Mark) }\end{array}$ & $-0.006^{*}$ & $-0.006^{*}$ & -0.005 & -0.005 \\
\hline Individual inventor & $0.624 * * *$ & $0.624^{* * *}$ & $0.577 * * *$ & $0.548^{* * *}$ \\
\hline Pre-patent licensing & $0.216 * *$ & $0.210 * *$ & $0.182^{*}$ & $0.182^{*}$ \\
\hline Inventor milestone & & 0.085 & 0.093 & 0.090 \\
\hline Auditing right & & & $-0.217^{*}$ & -0.193 \\
\hline Producer milestone & & & & $0.194^{*}$ \\
\hline Constant & $0.418^{* * *}$ & $0.412^{* * *}$ & $0.422^{* * *}$ & $0.382^{* * *}$ \\
\hline McFadden $\mathrm{R}^{2}$ & 0.342 & 0.343 & 0.356 & 0.371 \\
\hline Prob $\mathrm{Chi}^{2}$ test & 0.000 & 0.000 & 0.000 & 0.000 \\
\hline Number of observations & 180 & 180 & 180 & 180 \\
\hline
\end{tabular}

Method: Probit. ${ }^{*}, * * * * * *$ denotes significance on ten, five, and one percent level, respectively.

The Probit regressions employ a zero-one coded dummy variable taking the value of one if the contract specifies a profit share. The explanatory dummy variable 'pre-patent licensing' takes the value of one if the licensing contract is closed before a patent is granted for the licensed technology. We expect a significantly positive coefficient for this variable. The dummy variable 'individual inventor' takes the value of one if the licensor is an individual. We expect a significantly positive coefficient for this variable. The variable 'fixed fee' reflects the size of the upfront fixed fee (in 1,000 Mark) paid by the firm to the inventor. If the inventor is risk-neutral, this variable should be insignificant. If the inventor is risk-averse, this variable should be significantly positive.

Our stability check employs three additional variables capturing contractual clauses. The dummy variable 'inventor milestone' takes the value of one if the licensing contract specifies a fixed payment of the firm to the inventor if a certain milestone is reached. Dechenaux et al. (2009)

26 Using only observations from the chemical industry and using firm fixed effect does not affect the results. Results are available upon request. 
show that milestone payments can also be used to overcome the moral hazard problem between inventor and firm. Consequently, milestone payments can substitute profit shares - this would be reflected in a significantly negative coefficient - or they can complement profit shares - this would result into a significantly positive coefficient. Moreover, the dummy variable 'producer milestone' takes the value one if the contract specified a payment to the licensor if the producers reach some specified target. The model proposed by Decheneaux et al. (2011) suggests that riskaverse licensees use this kind of instrument since it specified only a payment in case of a commercial success of a product. Table 4 presents the results.

As expected, pre-patent contracting and contracting with individual inventors positively affects the probability of a profit sharing agreement. For non-patented innovations, the probability of closing a profit-sharing agreement is at least 18.2 percent larger than for a patented innovation. If the licensor is an individual inventor, the probability of agreeing on a profit-sharing agreement is at least 47.8 percent larger compared to the case with a firm as licensor. The marginal effect of a fixed upfront fee is slightly negative and generally insignificant. This can be taken as evidence for nearly risk-neutral licensors.

Furthermore, the result regarding the inventor milestone suggests that inventor moral hazard was not the driving force behind profit sharing contracts. Uncertainty regarding future profits and risk-averse licensee are a more likely candidate. This claim is supported by the insignificant effect of inventor milestones on profit shares. If post contracting inventor effort is important inventor milestones should substitute or complement profit shares. Producer milestones may affect the contract design. But the empirical evidence for this claim is rather thin since the variable is only marginally significant.

So far, we were only concerned with the determinants of the probability of agreeing on a profitsharing agreement. We now turn to the quantitative effects of a contractual clause on the size of profit shares. From theory, we expect that higher fixed upfront payments are correlated with higher profit shares if the inventor is risk-averse. Moreover, early-stage inventions licensed by an individual inventor should have higher profit shares since more effort of the licensor is necessary to commercialise the innovation.

The dependent variable in the regressions $(5 a)$ and $(5 b)$ in Table 5 is the mean profit share agreed upon in a contract. If the contract specifies different profit shares for different states of the world (e.g., levels of profits or output), we use the arithmetic mean of all profit shares mentioned in the contract. For example, a contract might specify a profit share of 10 percent for the profits generated by the first 10,000 units and a profit share of 5 percent for the profits from all other units. We then employ the mean profit share of 7.5 percent as dependent variable. The explanatory variables are the same as above in Table 4. In addition, we use the first profit share agreed upon in the contract as dependent variable in regressions (5c) and (5d). Implicitly, the specification used in regressions (5a) and (5b) assumes that all states of the world specified in the contract have the same probability and we can use the average of all profit shares specified for different stats of the world as a dependent variable. However, inventor or producer effort might be more important to 
reach the first state of the world, whereas the other states of the world are dominated by events outside the control of the licensor and licensee, e.g., market demand or the existence of substitutes. Table 5 presents the results based on a sample of 114 profit-sharing agreements. These contracts were all closed in the chemical and pharmaceutical industry.

Table 5: Explaining the size of profit shares in licensing contracts of the chemical industry

\begin{tabular}{lcccc}
\hline & $\begin{array}{c}\text { Average profit } \\
\text { share }\end{array}$ & $\begin{array}{c}\text { Average profit } \\
\text { share }\end{array}$ & $\begin{array}{c}\text { First profit } \\
\text { share }\end{array}$ & $\begin{array}{c}\text { First profit } \\
\text { share }\end{array}$ \\
\hline Fixed fee (in 1,000 & -0.074 & 0.193 & -0.085 & 0.276 \\
Mark) & $-5.379^{* * *}$ & $-5.568^{* *}$ & $-4.745^{* * *}$ & $-3.528^{* * *}$ \\
Producer milestone & 0.412 & -0.127 & -0.317 & -1.197 \\
Inventor milestone & -3.479 & -4.452 & -6.142 & -7.508 \\
Individual inventor & -0.303 & 0.161 & 0.661 & 0.816 \\
Pre-patent licensing & 8.806 & 9.268 & $10.163^{* *}$ & $9.911^{*}$ \\
Auditing & & -30.560 & & -40.626 \\
BASF licensee & & -2.147 & & -1.399 \\
Bayer licensee & -0.958 & & -3.771 \\
Hoechst licensee & & 0.937 & & 1.997 \\
Merck licensee & $21.578^{* * *}$ & $22.033^{* * *}$ & $22.222^{* * *}$ & $23.067 * * *$ \\
Constant & 0.110 & 0.092 & 0.152 & 0.173 \\
adjusted $\mathrm{R}^{2}$ & 0.005 & 0.027 & 0.005 & 0.001 \\
Prob F-Test & 114 & 114 & 114 & 114 \\
Number of observations & & & & \\
\hline
\end{tabular}

Method: OLS with heteroscedasticity corrected standard errors.

$* * * * * *$ denotes significance on ten, five, and one percent level, respectively.

In contrast to our theoretical expectations, neither the dummy variable capturing pre-patent contracting nor the dummy variable capturing that the licensor is an individual affects the size of the profit shares. Moreover, the size of the fixed upfront payment does not affect the size of the profit share.

In some cases, contracts giving the inventor the right to inspect the accounts of the firm allocate a higher profit share to the inventor. We can think of at least two explanations for this finding: it becomes more important to have an auditing right if the profit share is higher; or inventors getting the right to inspect the accounts might be inventors with substantial bargaining power. However, bargaining power and costly state verification is not included in licensing models. Moreover, milestones can, as expected from theory, be used as a substitute for profit shares. Including a producer milestone into the contract reduces the profit share agreed upon significantly, whereas inventor milestones turn out to be insignificant. 


\section{Conclusion}

We provide evidence that a modern licensing market emerged as early as 1880 in Germany and this market was quite similar to modern technology markets. Using a sample of 180 technology licensing agreements sealed by a sample of firms between 1880 and 1914, we show that licensing contracts in chemicals, pharmaceuticals, and electrical engineering often contained fixed upfront payments and in nearly all cases royalties based on profits, revenues, or physical output. Profit-sharing contracts were the most common type of agreement. Moreover, many contracts were sealed between individual inventors and firms. Consequently, profit-sharing or equitysharing licensing contracts are not a recent phenomenon as, for example, argued by Feldman et al. (2002) or Sampat (2006). Such contracts were already in use more than one century ago.

A regression analysis reveals that contracts closed by potentially competing firms contained turnover sharing rules or per-unit royalties to account for strategic concerns of the licensor. Moreover, inventor moral hazard seems to be relatively unimportant, whereas uncertainty regarding the expected profits of a licensed technology were of outstanding importance for the design of technology licensing contracts. In contrast to some theoretical models, uncertainty was not dealt with turnover sharing clauses or per-unit royalties. Instead, profit sharing agreements and producer milestones dominated contract design. Thus, late $19^{\text {th }}$ and early $20^{\text {th }}$ century contract designers were very efficient since the mostly agreed upon contract design without deadweight losses. Contract designs which are inefficient from a social welfare perspective were regularly used to address strategic concerns of licensors. 


\section{References}

\section{Primary Sources}

Corporate Archive BASF AG, Ludwigshafen

$\mathrm{E} / 2 / 10 / 5$

T 81

Urkunden der Badischen Anilin- und Soda-Fabrik Ludwigshafen a. Rh., Vol. 1 \& 2

Deutsches Technikmuseum, Berlin

I.2.060 A 00060

I.2.060 A 03387

I.2.060 A 03722

I.2.060 A 04516

I.2.060 A 04517

I.2.060 A 04626

I.2.060 A 05976

I. $2.060 \mathrm{C} 01375$

I.2.060 C 01522

I. $2.060 \mathrm{C} 02677$

I. $2.060 \mathrm{C} 02692$

I.2.060 C 02799

I. $2.060 \mathrm{C} 02876$

I. $2.060 \mathrm{C} 03020$

I. $2.060 \mathrm{C} 03027$

I.2.060 C 03034

I.2.060 C 03048

I. $2.060 \mathrm{C} 03080$

I.2.060 C 03116

I. $2.060 \mathrm{C} 03134$

HistoCom GmbH, Frankfurt/Main-Höchst

Auswärtige Mitarbeiter (formerly: C/1/2/a Auswärtige Mitarbeiter)

Chronik der pharmazeutischen Abteilung

Dokumente aus Hoechster Archiven 25 (1967)

Dokumente aus Hoechster Archiven 32 (1968)

Dokumente aus Hoechster Archiven 47 (1975)

Emil Fischer (formerly: C/1/3/f Emil Fischer)

Gl 3.9.4. - 1

Gl 14.5/1

Gl 14.6/1

G1 $38 / 3$

Gl 42/1

L. Knorr (formerly: C/1/2/b Knorr) 
Corporate Archive Bayer AG, Leverkusen

$$
\text { 019/A-032 }
$$

019/A-033

019/A-033-001

019/A-040

019/A-043

019/A-059

019/A-065

019/A-067

019/A-073-001

019/A-091

019/A-093

019/A-111

019/A-115

019/A-125

019/A-128

019/A-133

019/A-135

019/A-140

019/A-154

019/A-157

019/A-166

019/A-177-001

019/A-177-004

019/A-196

019/A-211

019/A-235

019/A-312

019/A-313

019/A-347

019/A-353

019/A-371-001

019/A-371-002

019/A-381-001

019/A-409

019/A-410-001

019/A-440

019/A-485-001

019/A-487-001

019/A-492

019/A-492-002

019/A-496

019/A-502

019/A-512

019/A-530-003

Corporate Archive E. Merck, Darmstadt

R $1 / 42$

R $5 / 23$

R $15 / 11$

R $15 / 12$

Siemens AG Corporate Archives, Munich 2401

4351

5029 


\section{Secondary Sources}

Abelshauser, W. (2002)

Die BASF: Eine Unternehmensgeschichte

C.H. Beck, München

Aghion, P. and Tirole, J. (1994a)

Opening the black box of innovation

European Economic Review, 38, 701-710

Aghion, P. and Tirole, J. (1994b)

The management of innovation

Quarterly Journal of Economics, 109, 1185-1209

Agrawal, A. (2006)

Engaging the inventor: Exploring licensing strategies for university inventions and the role of latent knowledge

Strategic Management Journal, 27, 63-79

Anand, B.N. and Khanna, T. (2000)

The structure of licensing contracts

Journal of Industrial Economics, 48, 103-135

Arora, A., Ceccagnoli, M., and Cohen, W.M. (2007)

Trading knowledge: An explorations of patent protection and other determinants of market transactions in technology and R\&D

In: Lamoreaux, N.R. and Sokoloff, K.L. (Eds.), Financing innovation in the United

States, 1870 to the present, MIT Press, Cambridge / Mass., 2007, 365-403

Baten, J., Spadavecchia, A., Streb, J., and Yin, S. (2007)

What Made Southwestern German Firms Innovative around 1900? Assessing

the importance of intra- and inter-industry externalities

Oxford Economic Papers, 59, Special Issue, i105-i126

Beer, J.J. (1959)

The emergence of the Germany dye industry

The University of Illinois Press, Urbana

Borscheid, P. (1976)

Naturwissenschaft, Staat und Industrie in Baden, 1848-1914

Ernst Klett, Stuttgart

Bousquet, A., Cremer, H., Ivaldi, M. and Wolkowicz, M. (1998)

Risk sharing in licensing

International Journal of Industrial Organization, 16, 535-554

Brousseau, E., Coeurderoy, R., and Chaserant, C. (2007)

The governance of contracts: Empirical evidence on technology licensing agreements

Journal of Institutional and Theoretical Economics, 163, 205-235

Burhop, C. (2009)

Pharmaceutical research in Wilhelmian Germany: The case of E. Merck

Business History Review, 83, 475-503

Burhop, C. (2010)

The transfer of patents in Imperial Germany

Journal of Economic History, 70, 921-939

Burhop, C. and Wolff, G.B. (2005)

A compromise estimate of German net national product, 1851-1913, and its implications for growth and the business cycle

Journal of Economic History, 65, 613-657 
Burhop, C. and Lübbers, T. (2009)

Incentives and innovation? R\&D management in Germany's chemical and electrical engineering industries around 1900

Explorations in Economic History, 47, 100-111

Dechenaux, E., Thursby, M., and Thursby, J. (2010)

Shirking, sharing risk and shelving: The role of university licensing contracts

International Journal of Industrial Organization, 27, 80-91

Dechenaux, E., Thursby, M., and Thursby, J. (2011)

Inventor moral hazard in university licensing: The role of contracts

Research policy, 40, 94-104

Erker, P. (1990)

Zur Geschichte der Industrieforschung in den europäischen und amerikanischen Elektrokonzernen, 1890-1930

Zeitschrift für Unternehmensgeschichte, 35, 1990, 73-94

Feldenkirchen, W. (2003)

Siemens: Von der Werkstatt zum Weltunternehmen

Piper, München

Feldmann, M., Feller, I., Bercovitz, J., and Burton, R. (2002)

Equity and the technology transfer strategies of American research universities Management Science, 48, 105-121

Galini, N.T. and Wright, B.D. (1990)

Technology transfer under asymmetric information

RAND Journal of Economics, 21, 147-160

Haber, L.F. (1958)

The chemical industry during the nineteenth century: A study of the economic aspect of applied chemistry in Europe and North America

Claredon Press, Oxford

Hack, L. (1998)

Technologietransfer und Wissenstransformation: Zur Globalisierung der

Forschungsorganisation von Siemens

Westfälisches Dampfboot, Münster

Heggen, A. (1975)

Erfindungsschutz und Industrialisierung in Preußen, 1793-1877

Vandenhoeck \& Ruprecht, Göttingen

Hoffmann, W.G. (1965)

Das Wachstum der deutschen Wirtschaft seit der Mitte des 19. Jahrhunderts

Springer, Berlin

Homburg, E. (1992)

The emergence of research laboratories in the dyestuffs industry, 1870-1900

British Journal for the History of Science, 25, 91-111

Homburg, E., Travis, A.S., and Schröter, H.G. (Eds, 1998)

The chemical industry in Europe, 1850-1914: Industrial growth, pollution, and professionalization

Kluwer, Dordrecht

Jensen, R. and Thursby, M. (2001)

Proofs and prototypes for sale: The licensing of university inventions

American Economic Review, 91, 240-259

Kamien, M.I. and Tauman, Y. (1986)

Fees versus royalties and the private value of a patent.

Quarterly Journal of Economics, 101, 471-491

Katz, M.L. and Shapiro, C. (1985)

On the licensing of innovations

RAND Journal of Economics, 16, 504-520 
Khan, B.Z. (1995)

Property rights and patent litigation in early nineteenth-century America Journal of Economic History, 55, 58-97

Khan, B.Z. and Sokoloff, K.L. (1993)

„Schemes of practical utility“: Entrepreneurship and innovation among „Great in“ ventors" in the United States, 1790-1865

Journal of Economic History, 53, 289-307

Khan, B. Z. and Sokoloff, K.L. (2004)

Institutions and democratic invention in the 19th-century America: Evidence from the „Great inventors“, 1790-1930

American Economic Review, Papers and Proceedings, 94, 395-401

Kocka, J. (1969)

Unternehmensverwaltung und Angestelltenschaft am Beispiel Siemens, 1847-1914:

Zum Verhältnis von Kapitalismus und Bürokratie in der deutschen Industrialisierung

Ernst Klett, Stuttgart

König, W. (1996)

Science-based industry or industry-based science? Electrical engineering in Germany before World War I

Technology and Culture, 37, 70-101

Lamoreaux, N.R. and Sokoloff, K.L. (1999)

Inventors, firms, and the market for technology in the late nineteenth and early twentieth centuries

In: Lamoreaux, N.R., Raff, D.G., and Temin, P. (Eds.): Learning by doing in markets, firms, and countries, University of Chicago Press, Chicago 1999, 19-57.

Lamoreaux, N.R. and Sokoloff, K.L. (2000)

The geography of invention in the American glass industry, 1870-1925

Journal of Economic History, 60, 700-729

Lamoreaux, N.R. and Sokoloff, K.L. (2001)

Market trade and patents in the rise of a class of specialized inventors in the $19^{\text {th }}$ century United States

American Economic Review, Papers and Proceedings, 91, 39-44

Lübbers, T. (2009)

Unternehmenskooperation auf dem Gebiet gewerblicher Schutzrechte in der chemischen, pharmazeutichen und elektrotechnischen Industrie, 1880-1914

Vierteljahrschrift für Sozial- und Wirtschaftsgeschichte, 95, 147-172

Mendi, P. (2005)

The structure of payments in technology transfer contracts: Evidence from Spain Journal of Economics and Management Strategy, 14, 403-429

Mowery, D.C. (1983)

The relationship between intrafirm and contractual forms of industrial research in

American manufacturing, 1900-1940

Explorations in Economic History, 20, 351-374

Murmann, J.P. (2006)

Knowledge and competitive advantage

Cambridge University Press, Cambridge

Nicholas, T. (2009)

Spatial diversity in invention: Evidence from early R\&D labs

Journal of Economic Geography, 9, 1-31

Nicholas, T. (2010)

The role of independent invention in U.S. technological development, 1880- 1930

Journal of Economic History, 70, 57-82 
Nicholas, T. (2011)

Independent invention during the rise of the corporate economy in Britain and Japan

Economic History Review, 2011, in print

Pierenkemper, T. and Tilly, R.H. (2004)

The German economy during the nineteenth century

Berghan, New York

Pohl, M. (1988)

Emil Rathenau und die AEG

AEG, Berlin

Reinhardt, C. (1995)

Vom Alizarinblau zum Thallin: Pharmazeutisch-chemische Forschung der BASF in den achtziger Jahren des 19. Jahrhunderts

In: Schütt H., Weiss, B., eds., Brückenschläge. 25 Jahre Lehrstuhl für Geschichte der exakten Wissenschaften und der Technik an der Technischen Universitat Berlin Verlag für Wissenschafts- und Regionalgeschichte, Berlin, 253-276

Reinhardt, C. (1997)

Forschung in der chemischen Industrie: Die Entwicklung synthetischer Farbstoffe bei BASF und Hoechst, 1863-1914

Unpublished $\mathrm{PhD}$-Thesis, Technische Universität der Bergakademie Freiberg

Reinhardt, C. and Travis A. S. (2000)

Heinrich Caro and the Creation of Modern Chemical Industry

Kluwer, Dordrecht

Sakakibara, M. (2010)

An empirical analysis of pricing in patent licensing contracts

Industrial and Corporate Change, 19, 927-945

Sampat, B.N. (2006)

Patenting and US academic research in the 20th century: The world before Bayh-

Dole

Research Policy, 30, 772-789

Schubert, H. (1987)

Industrielaboratorien für Wissenschaftstransfer: Aufbau und Entwicklung der Siemensforschung bis zum Ende des Zweiten Weltkriegs anhand von Beispielen aus der Halbleiterforschung

Centaurus, 30, 245-292

Schulz-Hanßen, K. (1970)

Die Stellung der Elektroindustrie im Industrialisierungsprozeß

Duncker \& Humblot, Berlin

Scotchmer, S. (2006)

Innovation and Incentives

MIT Press, Cambridge / Mass.

Seckelmann, M. (2006)

Industrialisierung, Internationalisierung und Patentrecht im Deutschen Reich, 1871-1914

Vittorio Klostermann, Frankfurt am Main

Shapiro, C. (1985)

Patent licensing and R\&D rivalry

American Economic Review, 75, 25-30

Streb, J., Baten, J., and Yin, S. (2006)

Technological and geographical knowledge spillover in the German Empire, 1877-

1914

Economic History Review, 59, 343-373 
Strunk, P. (2000)

Die AEG: Aufstieg und Niedergang einer Industrielegende $2^{\text {nd }}$ Edition, Nicolaische Verlagsbuchhandlung, Berlin

Trendelenburg, F. (1975)

Aus der Geschichte der Forschung im Hause Siemens

VDI Verlag, Düsseldorf

Vishwasrao, S. (2007)

Royalties vs. fees: How do firms pay for foreign technology?

International Journal of Industrial Organization, 25, 741-759

Wang, X.H. (1998)

Fee versus royalty licensing in a Cournot duopoly model

Economics Letters, 60, 55-62

Weiher, S. von and Goetzler, H. (1981)

Weg und Wirken der Siemens-Werke im Fortschritt der Elektrotechnik, 1847-1980:

Ein Beitrag zur Geschichte der Elektroindustrie

Zeitschrift für Unternehmensgeschichte, Supplement 21

Wetzel, W. (1991)

Naturwissenschaften und chemische Industrie in Deutschland: Voraussetzungen und Mechanismen ihres Aufstiegs im 19. Jahrhundert

Franz Steiner, Stuttgart

Wimmer, W. (1994)

„Wir haben fast immer was Neues“: Gesundheitswesen und Innovation in der Pharma-Industrie in Deutschland, 1880-1935

Duncker \& Humblot, Berlin 